\title{
PROTHROMBIN CONSUMPTION IN HAEMOPHILIAC KINDRED
}

\author{
BY \\ R. L. MACMILLAN, C. EZRIN, AND A. BUTLER \\ From the Departments of Medicine and Zoology, the University of Toronto
}

(RECEIVED FOR PUBliCATION MARCH 9, 1951)

In 1911 Addis noted that patients with haemophilia are unable to use prothrombin. This observation has been extended by Milstone (1948) and Quick (1947) with the development by the latter of the prothrombin consumption test and its later modification (Quick and Favre-Gilly, 1949). It has been hoped that this test would prove a diagnostic aid in the recognition of haemophilia, especially in those cases where the clotting time is within normal limits or only slightly prolonged. Recently such a case came under observation at the Toronto General Hospital.

\section{Case Report}

Victor B., a 19-year-old French Canadian boy, had three molar teeth extracted on December 21, 1949. Bleeding occurred from the sockets, and despite local measures, such as suturing the gums, the application of topical thrombin, and of local adrenaline, it continued for the next two weeks. He was admitted to the Toronto General Hospital on January 4, 1950. At this time the haemoglobin was $68 \%$ (10.6 g.) and the clotting time was 14 minutes by the modified Lee and White method, which was considered to be at the upper limit of normal. A prothrombin consumption test showed moderate but definite impairment of prothrombin utilization. A diagnosis of haemophilia was made. It was learned from a brother that abnormal bleeding had occurred in several male members of the family.

During the next eight days the patient received $6,000 \mathrm{ml}$. of fresh dextrated blood with an immediate decrease in the severity of the bleeding. After the last transfusion slight oozing persisted for another week. During the transfusions of fresh blood the clotting time and prothrombin consumption were found to be normal, but quickly reverted to their former levels when therapy was stopped.

Several years before the patient had experienced a similar episode of uncontrollable bleeding after tooth extraction which necessitated admission to another hospital for transfusions. The patient did not see fit to divulge this information until towards the end of his stay in hospital. There was no history of joint pain, epistaxis, haematuria, or bleeding from the bowel. He stated that minor wounds bled profusely.

The patient belonged to a prolific family living in the vicinity of North Bay, Ontario. It was decided to conduct a field trip to investigate (1) the history of bleeding; (2) clotting time; (3) prothrombin consumption three hours after the blood had clotted; and (4) hereditary characteristics including colour vision, taste blindness to phenyl-thio-carbamide, eye colours, tongue curling, blood groups A, B, O, M, N, and common Rh sub-types. 


\section{Procedure}

Clotting time was measured at room temperature (approximately $15^{\circ} \mathrm{C}$.). One millilitre of blood was placed in a small test-tube measuring $10 \mathrm{~mm}$. in internal diameter. The tube was tilted every 30 seconds and the end-point was taken when gentle tapping would no longer cause the blood to flow.

Prothrombin consumption was measured by allowing approximately $5 \mathrm{ml}$. of venous blood to clot. After one and one half hours the clotted blood was centrifuged. At three hours the prothrombin time of the serum was measured by the addition of $0.1 \mathrm{ml}$. of serum to 0.1 portions of Seitz-filtered human plasma, thromboplastin (Difco), and 0.025 molar calcium chloride solution. The mixture was placed in a water bath at $37^{\circ} \mathrm{C}$. The appearance of clot constituted the end-point The Seitz-filtered plasma provided a source of fibrinogen. It had been stored for a week, and on testing no prothrombin activity was observed. A short prothrombin consumption time indicated an impairment in prothrombin utilization such as is found in haemophilia.

\section{Results and Discussion}

The co-operation of the family was extremely satisfactory, as 85 members attended (Fig. 1). Twelve of the males had definite history of bleeding. Nine of these are still alive. The disease seemed to be uniformly mild in this family, as only one instance of haemarthrosis was noted, that in Rene B., the patient's brother, who later bled to death following a tonsillectomy.

The results of the prothrombin consumption test and the clotting times are presented in Table I. The mean clotting time of the bleeders was significantly higher than that of either the unaffected males or females. Similarly the prothrombin

TABLE I

Comparison of Haemophiliac and Normal Groups with Regard to Prothrombin Consumption Time, Clotting Time, AND Age

\begin{tabular}{|c|c|c|c|c|c|}
\hline Factor & Group & No. & Mean & S.D. & Difference in Means \\
\hline $\begin{array}{l}\text { Prothrombin con- } \\
\text { sumption time } \\
\text { (sec.) }\end{array}$ & $\begin{array}{l}\text { Haemophiliacs } \\
\text { Females } \\
\text { Unaffected males }\end{array}$ & $\begin{array}{r}8 \\
27 \\
32\end{array}$ & $\begin{array}{l}37 \cdot 3 \\
45 \cdot 7 \\
54 \cdot 2\end{array}$ & $\begin{array}{l}13 \cdot 4 \\
13 \cdot 2 \\
12 \cdot 9\end{array}$ & $\begin{array}{l}\text { Females and haemophiliacs. } \\
\text { Diff. }=8 \cdot 4 . \ddagger t=1 \cdot 58 \\
\text { Unaffected males and haemo- } \\
\text { philiacs. Diff. }=16.9 . * t=3 \cdot 28 \\
\text { Unaffected males and females. } \\
\text { Diff. }=8 \cdot 5 . \dagger \quad t=2 \cdot 49\end{array}$ \\
\hline $\begin{array}{l}\text { Clotting time } \\
\text { (min.) }\end{array}$ & $\begin{array}{l}\text { Haemophiliacs } \\
\text { Females } \\
\text { Unaffected males }\end{array}$ & $\begin{array}{r}7 \\
22 \\
29\end{array}$ & $\begin{array}{l}19 \cdot 1 \\
15 \cdot 7 \\
13 \cdot 9\end{array}$ & $\begin{array}{l}5 \cdot 14 \\
3 \cdot 37 \\
2 \cdot 98\end{array}$ & $\begin{array}{l}\text { Females and haemophiliacs. } \\
\text { Diff. }=3.4 . \dagger t=2.05 \\
\text { Unaffected males and haemo- } \\
\text { philiacs. Diff. }=5 \cdot 2 .^{*} \mathrm{t}=3.61 \\
\text { Unaffected males and females. } \\
\text { Diff. }=1 \cdot 8 . \dagger \quad t=2.02\end{array}$ \\
\hline Age & $\begin{array}{l}\text { Haemophiliacs } \\
\text { Females } \\
\text { Unaffected males }\end{array}$ & $\begin{array}{r}8 \\
27 \\
32\end{array}$ & $\begin{array}{l}13 \cdot 1 \\
18 \cdot 2 \\
20 \cdot 3\end{array}$ & $\begin{array}{l}5 \cdot 75 \\
11 \cdot 3 \\
17 \cdot 4\end{array}$ & $\begin{array}{l}\text { Females and haemophiliacs. } \\
\text { Diff. }=5 \cdot 1 . \ddagger t \mathrm{t}=1 \cdot 23 \\
\text { Unaffected males and haemo- } \\
\text { philiacs. Diff. }=7 \cdot 2 . \ddagger \mathrm{t}=1 \cdot 15 \\
\text { Unaffected males and females. } \\
\text { Diff. }=2 \cdot 1 . \ddagger \quad t=0.54\end{array}$ \\
\hline
\end{tabular}

* Difference is statistically significant at the 0.01 level of confidence.

+ Difference is statistically significant at the 0.05 level of confidence.

$\ddagger$ Difference is not statistically significant. 
consumption time of the bleeders differed significantly from the unaffected groups, the mean of the former being lower. Thus it was possible by means of either of the two tests to differentiate on a group basis between haemophiliac males and unaffected members. However, due to the number of haemophiliacs having prothrombin consumption times and clotting times within the normal range, these tests were not considered sufficiently reliable for individual diagnosis.

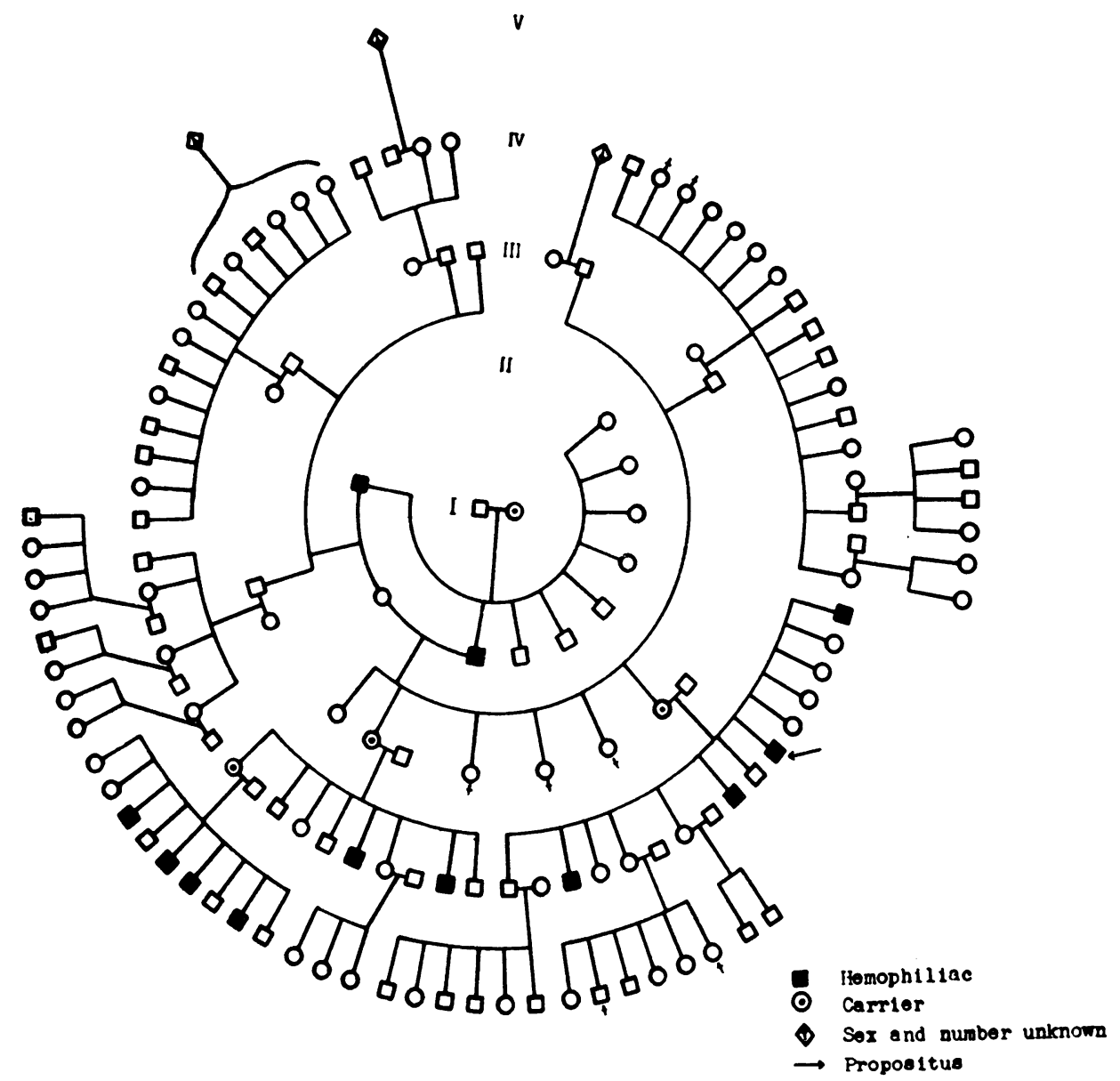

FIG. 1.-Pedigree showing five generations. The propositus (Victor B.) is indicated by arrow in the fourth generation.

Quick (1951) believes the prothrombin consumption test to be a valuable new means of establishing a diagnosis of haemophilia, and allows the diagnosis to be made even in the atypical case and before any abnormal bleeding has occurred. It must be emphasized that the present survey was carried out in the field under rather primitive conditions, and it is possible that different results might have been obtained in the laboratory, where a more complete investigation of prothrombin consumption 
could have been carried out by means of methods described by Quick (1947) and Merskey (1950).

The mean prothrombin consumption time for three affected males, aged 19-21, was 29 , while that of five affected, aged 6 to 12, was 42 . Also, only $9 \%$ of the normal group had times shorter than 37 seconds, the longest time obtained for the older group. This suggests that in children the prothrombin consumption test is less helpful than in adults. If prothrombin consumption time depends on age, unsatisfactory results would be obtained by comparing haemophiliacs with normals of a different age range. In the present study, the mean age (see Table I) of haemophiliacs was lower than the mean ages of the unaffected groups. These differences in ages, however, were not statistically significant. Within unaffected males, there was no significant correlation (product moment $r=-0.241$ ) between age and prothrombin consumption time. Furthermore, due to the smallness of the haemophiliac group the results are only suggestive of a possible relationship in haemophilia between age and prothrombin consumption time.

Two incidental findings, which may be significant in another context, are presented in Table I. First, the prothrombin consumption time of the females tended to be lower than that of unaffected males. Secondly, the clotting time of the females tended to be longer than that of unaffected males.

Data concerning the hereditary characteristics were obtained for two reasons. Colour vision was investigated in the hope of adding to previous data on the sexlinkage of haemophilia and colour blindness. All the individuals examined, however, had normal colour vision. In the event of identifying different degrees of severity of the disease, the autosomally inherited characteristics were studied for their possible genetic linkage with a modifying factor. As the condition was found to be uniformly mild, this linkage study was not carried out.

\section{Summary}

Eighty-five members of haemophiliac kindred were investigated by means of a field survey. The disease was uniformly mild, and under the conditions of the present study the clotting time and prothrombin consumption are of limited value in diagnosis in the individual case. Without a history of excessive bleeding a diagnosis of haemophilia would not have been made with any degree of certainty. It was possible by these tests to differentiate, only on a group basis, haemophiliac males from unaffected members.

The funds for this investigation were provided by the Banting Research Foundation. We should like to thank Dr. K. J. R. Wightman for his interest and co-operation; Mr. A. D. McClure, Director, Provincial Laboratory, North Bay, for his assistance ; and the remainder of the medical and technical team for their enthusiastic support.

\section{REFERENCES}

Addis, T. (1911). J. Path. Bact., 15, 427.

Merskey, C. (1950). J. clin. Path., 3, 130.

Milstone, J. H. (1948). Proc. Soc. exp. Biol., N.Y., 68, 225.

Quick, A. J. (1947). Amer. J. med. Sci., 214, 272.

- (1951). J. Amer. med. Ass., 145, 4.

- and Favre-Gilly, J. E. (1949). Blood, 4, 1281. 